\title{
Article \\ Natural Radioactivity and Radon Exhalation from Building Materials in Underground Parking Lots
}

\author{
Dainius Jasaitis *(D) and Milda Pečiulienè \\ Department of Physics, Vilnius Gediminas Technical University, Sauletekio Ave. 11, LT-10223 Vilnius, Lithuania; \\ milda.peciuliene@vilniustech.lt \\ * Correspondence: dainius.jasaitis@vilniustech.lt
}

Citation: Jasaitis, D.; Pečiulienė, M. Natural Radioactivity and Radon Exhalation from Building Materials in Underground Parking Lots. Appl. Sci. 2021, 11, 7475. https://doi.org/ 10.3390/app11167475

Academic Editor: Francesco Caridi

Received: 16 June 2021

Accepted: 12 August 2021

Published: 14 August 2021

Publisher's Note: MDPI stays neutral with regard to jurisdictional claims in published maps and institutional affiliations.

Copyright: (c) 2021 by the authors. Licensee MDPI, Basel, Switzerland. This article is an open access article distributed under the terms and conditions of the Creative Commons Attribution (CC BY) license (https:// creativecommons.org/licenses/by/ $4.0 /)$.

\begin{abstract}
The change of natural ionizing radiation and the radon exhalation rates from typical building materials in underground parking lots are presented in the article. The activity concentration of natural radionuclides ${ }^{232} \mathrm{Th},{ }^{226} \mathrm{Ra}$, and ${ }^{40} \mathrm{~K}$ in six important types of construction materials, which are mostly used in Lithuania, were analyzed using high-resolution gamma spectroscopy. The highest values were found in concrete and ferroconcrete samples: ${ }^{226} \mathrm{Ra} 44$ and $90 \mathrm{~Bq} \mathrm{~kg}{ }^{-1} ;{ }^{232} \mathrm{Th} 29$ and $34 \mathrm{~Bq} \mathrm{~kg}^{-1} ;{ }^{40} \mathrm{~K}_{581}$ and $603 \mathrm{~Bq} \mathrm{~kg}^{-1}$. A strong positive correlation (0.88) was observed between radium activity concentration and radon concentration. The activity indexes $\left(I_{\alpha}\right.$ and $\left.I_{\gamma}\right)$ and radium equivalent activity $\left(R_{\mathrm{eq}}\right)$ evaluating the suitability of materials for such constructions from the view of radiation safety were determined. The average values of the calculated absorbed dose rate in samples ranged from $18.24 \mathrm{nGy} \mathrm{h}^{-1}$ in the sand to $87.26 \mathrm{nGy} \mathrm{h}^{-1}$ in ferroconcrete. The calculated annual effective dose was below the limit of $1.0 \mathrm{mSv} \mathrm{y}^{-1}$. The values of the external and internal hazards index $\left(H_{\mathrm{ex}}\right.$ and $\left.H_{\text {in }}\right)$ were all below unity, and the values of $I_{\gamma}$ and $I_{\alpha}$ were below the recommended levels of 0.5 and 1. Dosimetric analysis of underground parking lots was carried out. It was determined that the external equivalent dose rate caused by the ${ }^{222} \mathrm{Rn}$ progeny radiation in the underground car parking lots varies from 17 to $30 \%$ of the total equivalent dose rate.
\end{abstract}

Keywords: natural radioactivity; radon exhalation; equivalent dose rate; car parking lots

\section{Introduction}

Ionizing radiation is one of the factors that can have a negative impact on human health. Natural radiation such as cosmic radiation, radionuclides in the soil and construction materials, radon gas are the highest sources of human radiation exposure. Even low doses of ionizing radiation can cause chronic diseases, cancer can also lead to various negative health effects. Negative consequences can occur many years after exposure. It is impossible to avoid the impact of radiation, but it can be reduced.

${ }^{226} \mathrm{Ra},{ }^{232} \mathrm{Th}$, and ${ }^{40} \mathrm{~K}$ in construction materials is an important source of human exposure [1,2]. Gamma radiation of these natural radionuclides causes external exposure. Building materials can be radioactive for various reasons, mostly due to the raw materials with a high activity concentration of natural radionuclides that are used for their production. Therefore, it is important to control the activity concentration of radionuclides in construction materials. One of the ways to reduce the external exposure dose is to select building materials with the low-level activity of radionuclides. Calculation of doses due to radionuclides in building materials is important from the point of radiation safety. High activities of natural radionuclides in building materials may be the cause of higher dose rates indoors, especially when products from various industries are used in the production process [3].

Radon exhalation from building materials is also an important problem as this radioactive inert gas is the most important source of internal exposure. According to some studies, radon and its decay products determine about $50 \%$ of the total dose from natural 
radiation $[4,5]$. Although the main source of radon indoors is soil, in some cases, the main sources of indoor radon can be construction materials-contribution is estimated to be up to $30 \%$ [6]. Radon is an alpha emitter; therefore, radon radiation is easily absorbed by human skin. However, radon gas can be inhaled by humans, and radon decay products $\left({ }^{218} \mathrm{Po},{ }^{214} \mathrm{~Pb}\right.$, and $\left.{ }^{214} \mathrm{Bi}\right) \mathrm{can}$ cause internal exposure [7]. The main risk posed by radon and its progeny is that it can cause respiratory tract and lung cancer. Radon disperses rapidly outdoors and is not a health issue. Most radon exposure occurs indoors where radon can have high activity concentration. It has been evaluated that the equivalent dose rate caused by ionizing radiation of radon progeny ${ }^{214} \mathrm{~Pb}$ and ${ }^{214} \mathrm{Bi}$ can vary from 2 to $20 \%$ of the total equivalent dose rate [8,9]. The average annual effective dose from natural sources is $2.4 \mathrm{mSv}$ : $1.1 \mathrm{mSv}$ of it is due to the basic background radiation, $1.3 \mathrm{mSv}$ due to exposure to radon [10]. According to Lithuanian Hygiene Norms and European Union directives, the indoor radon concentration must not exceed $300 \mathrm{~Bq} \mathrm{~m}^{-3}$ [11,12].

The exposure of radon progeny concentration in underground parking lots is determined by the ventilation intensity and radon exhalation from the soil and building materials. To reduce the amount of radioactive inert gas in parking places, it is necessary to study and use emanation blocking means in building materials; it is also important to know and control the activity concentration of ${ }^{226} \mathrm{Ra}$ in soil and building materials, as the intensity of radon exhalation depends on it [13]. It has been evaluated that the used quantity of building material and its particular place in a building determines the exposure [14].

In order for the population to be exposed to less radiation from radionuclides in construction materials, the activity concentration of radionuclides in building materials used in the construction must not exceed predefined limit values. Indoor radon research is carried out regularly. After assessing the exposure to ionizing radiation from radionuclides in building materials and the change and formation of this exposure, it is possible to plan measures that must be taken to optimally reduce the exposure.

Although the typical duration of stay for persons in underground parking lots is from a few minutes to a few hours per day, there are exceptions. In Lithuania, car cleaning centers, car wheel services, and various small repair workshops are found in the underground shopping centers. The people who work in them and customers spend a lot of time. Additionally, there are known cases when humans set up sports and training facilities and creative workshops in underground garages under apartment buildings. Therefore, it must be taken into account that some people can spend much more time in underground parking places than others. This is important from the point of view of radiation protection.

Identification of radiation sources, determination of exposure, investigation of variation, and distribution principles of radiation doses is an important stage of radiation safety optimization; therefore, it is important to analyze the human exposure sources and to choose the most optimal protection against ionizing radiation.

\section{Materials and Methods}

The measurements were undertaken in typical parking lots, located one floor below dwellings or shopping centers. Samples were taken in several ways. Some samples were collected from manufacturers and suppliers. Other samples, if it was possible, were taken at underground parking lots. For the statistical evaluation of the activity concentration distribution of natural radionuclides, 20 to 50 samples of the same material were taken.

To identify gamma radionuclides ${ }^{40} \mathrm{~K},{ }^{232} \mathrm{Th},{ }^{226} \mathrm{Ra}$ and measure their activity concentration the samples of the main building materials used for the construction of underground parking lots (clay, cement, sand, gravel, concrete, and ferroconcrete) were prepared for spectrometric analysis. The samples were dried at $105^{\circ} \mathrm{C}$ in a laboratory oven, then crushed and homogeneously put into measuring containers of $200 \mathrm{~mL}$ and left for four weeks to reach secular equilibrium between ${ }^{226} \mathrm{Ra}$ and its progeny. The samples were analyzed with the gamma spectrometry system Canberra, USA, with the semiconductor Hyper Pure germanium (HPGe) detector (model GC2520). HPGe detector has an energy resolution 
full width at half-maximum (FWHM) of $1.9 \mathrm{keV}$ at $1330 \mathrm{keV}\left({ }^{60} \mathrm{Co}\right)$. The detector has a high peak to Compton ratio of 58:1 and relative efficiency of 30\%. The samples of building materials were measured spectrometrically for at least $90000 \mathrm{~s} .{ }^{226} \mathrm{Ra}$ activity concentration in the samples was defined based on its decay products ${ }^{214} \mathrm{~Pb}(352 \mathrm{keV})$ and ${ }^{214} \mathrm{Bi}(609 \mathrm{keV})$, while ${ }^{232} \mathrm{Th}$ was defined based on ${ }^{228} \mathrm{Ac}(911 \mathrm{keV})$ and ${ }^{208} \mathrm{Tl}(583 \mathrm{keV}) .{ }^{40} \mathrm{~K}$ was determined directly according to the $1460 \mathrm{keV}$ energy gamma-radiation peak.

The radon exhalation rate was measured by hermetically closing the sample in a container and observing the radon activity growth as a time function $[3,15,16]$. The samples were kept in cylindrical containers of $400 \mathrm{~mL}$ capacity. LR-115 track detector was used in this study. The detector is exposed to the exhaled radon from the sample and fixes $\alpha$-particles resulting from the radon progeny in the volume of the container and ${ }^{218} \mathrm{Po}$ and ${ }^{214}$ Po deposited on the inner walls of the container. Following the long-term exposure, the LR-115 detector was chemically etched for developing the tracks registered in the films and the concentrations of radon and its decay products were determined.

The equivalent dose rate (EDR, $\mathrm{nSv} \mathrm{h}^{-1}$ ) caused by natural radionuclides in underground parking lots building materials was measured. Dosimetric measurements were performed using an InSpector 1000 a high-performance digital handheld multichannel analyzer with a NaI detector (IPROS-3), energy range $50 \mathrm{keV}$ to $3 \mathrm{MeV}$ [17]. The analyzer has computer interface software Genie 2000. The equivalent dose results are updated once per second. The parking lot where the EDR was measured (no closer than $50 \mathrm{~cm}$ from the wall) was split into imaginary squares with an edge length of $2 \mathrm{~m}$. The average EDR value of the five measurements was recorded at the center of each imaginary square with the detector held at a height of $1 \mathrm{~m}$. The number of measurement points depends on the size of the parking lot.

At the same time, radon concentration was measured using radon and thoron measurement system SARAD RTM2200. The monitor is based on $\alpha$-spectrometry forming ${ }^{222} \mathrm{Rn}$ progeny $\left({ }^{218} \mathrm{Po}\right.$ and $\left.{ }^{214} \mathrm{Po}\right)$ inside the high-quality silicon radiation detector chamber. Radon progeny deposit on the surface of the semiconductor detector and alpha radiation was registered. Measurement upper range of the radon concentration is $10 \mathrm{MBq} \mathrm{m}^{-3}$, device sensitivity -3 or $7 \mathrm{cpm} /\left(\mathrm{kBq} \cdot \mathrm{m}^{-3}\right)$ for fast or slow mode. Radon concentrations can be registered at different time intervals.

\section{Results and Discussion}

\subsection{Radon Exhalation Rate}

Radon surface and mass exhalation rates were calculated using Equations (1) and (2), respectively $[15,18]$.

$$
E_{\mathrm{S}}=\frac{C V \lambda / A}{T+(1 / \lambda)\left(e^{-\lambda T}-1\right)}
$$

and

$$
E_{\mathrm{M}}=\frac{C V \lambda / M}{T+(1 / \lambda)\left(e^{-\lambda T}-1\right)}
$$

where $E_{\mathrm{S}}$ is surface exhalation rate $\left(\mathrm{Bq} \mathrm{m}^{-2} \mathrm{~h}^{-1}\right) ; E_{\mathrm{M}}$ is mass exhalation rate $\left(\mathrm{Bq} \mathrm{kg}^{-1} \mathrm{~h}^{-1}\right)$; $C$ is integrated radon exposure $\left(\mathrm{Bq} \mathrm{m}{ }^{-3} \mathrm{~h}^{-1}\right) ; V$ is the volume of $\operatorname{air}\left(\mathrm{m}^{3}\right) ; \lambda$ is radon decay constant $\left(\mathrm{h}^{-1}\right) ; T$ is the exposure time $(\mathrm{h}), A$ is the surface area $\left(\mathrm{m}^{2}\right) \mathrm{m}$ and $M$ is the mass $(\mathrm{kg})$ of the sample, respectively.

Radon surface and mass exhalation rates and other parameters of the most commonly used building materials are presented in Table 1 . 
Table 1. Radon surface and mass exhalation rates and other parameters of studied building materials (M.V. $\pm \sigma)$.

\begin{tabular}{|c|c|c|c|c|c|}
\hline Building Material & $\begin{array}{c}\text { Rn Surface } \\
\text { Exhalation Rate } \\
\left(\mathrm{mBq} \cdot \mathrm{m}^{-2} \cdot \mathrm{h}^{-1}\right)\end{array}$ & $\begin{array}{c}\text { Rn Mass } \\
\text { Exhalation Rate } \\
\left(\mathrm{mBq} \cdot \mathrm{kg}^{-1} \cdot \mathrm{h}^{-1}\right)\end{array}$ & Emanation Factor (\%) & Porosity (\%) & $\begin{array}{l}\text { Bulk Density } \\
\quad\left(\mathrm{kg} \cdot \mathrm{m}^{-3}\right)\end{array}$ \\
\hline Sand & $10.2 \pm 1.5$ & $1.12 \pm 0.16$ & $5 \pm 0.7$ & $32 \pm 3.5$ & 1620 \\
\hline Clay bricks & $18.3 \pm 1.3$ & $1.22 \pm 0.15$ & $3 \pm 0.5$ & $23 \pm 3.2$ & 1950 \\
\hline Cement & $19.9 \pm 1.6$ & $1.19 \pm 0.13$ & $11 \pm 1.9$ & $12 \pm 2.2$ & 2020 \\
\hline Concrete & $24.3 \pm 1.2$ & $2.93 \pm 0.18$ & $10 \pm 1.3$ & $16 \pm 2.6$ & 2200 \\
\hline Ferroconcrete & $26.2 \pm 1.4$ & $2.95 \pm 0.17$ & $16 \pm 2.1$ & $18 \pm 2.9$ & 2400 \\
\hline
\end{tabular}

Radon surface exhalation rates vary from $10.2 \pm 0.5$ to $26.2 \pm 0.4 \mathrm{mBq} \mathrm{m}^{-2} \mathrm{~h}^{-1}$; radon mass exhalation rates vary from $1.12 \pm 0.06$ to $2.95 \pm 0.07 \mathrm{mBq} \mathrm{m}^{-2} \mathrm{~h}^{-1}$ (uncertainties are given with coverage factor $k=2$ ). The maximum rate of radon exhalation was observed in the concrete and ferroconcrete samples. It is worth mentioning that the radon exhalation rate changes with the age of the concrete. Various researchers [3,19-21] estimated that the radon exhalation rate was decreased with the increasing age of concrete. Additionally, it was estimated that the radon exhalation rate of concrete is reduced by low humidity conditions. Therefore, the results show that radon exhalation from samples of concrete measurements is dependent on the humidity and age of the sample and should be standardized.

Radon surface exhalation and mass exhalation rates found for sand are the lowest values and for concrete and ferroconcrete are found to be the maximum. The emanation fraction varies from 5 to $16 \%$. The results obtained in this work are within the values measured in other countries $[18,22-25]$. Correlation analysis showed a strong positive correlation ( 0.88 ) between radon concentration and radium activity concentration in various samples, which may be due to the radium content and porosity in the samples (Figure 1).

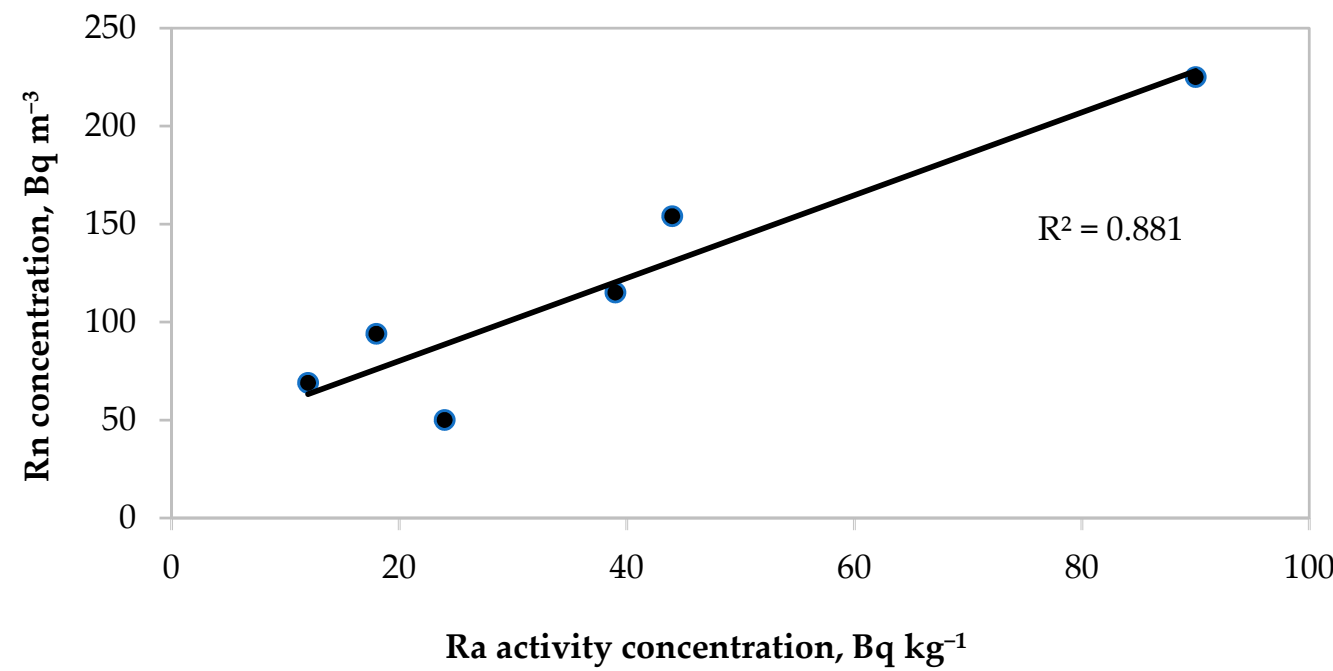

Figure 1. The correlation between radon concentration and radium activity concentration.

Research of radon activity concentrations in underground parking lots with workplaces has shown that people work in a safe environment in terms of radiation safety. The radon activity concentration varied from $22 \pm 3$ to $270 \pm 18 \mathrm{~Bq} \mathrm{~m}^{-3}$ (the average value was $83 \pm 7 \mathrm{~Bq} \mathrm{~m}^{-3}$ ). Indoor radon activity concentration did not exceed the level of the Lithuanian hygiene standard [11]. However, several cases were close to the maximum level. Such results may have been due to the fact that no mechanical ventilation systems were installed that do not allow radon to accumulate on the lower floors of the building. 


\subsection{Estimation of Radium, Thorium, and Potassium in Various Samples}

The activity concentration $\left(\mathrm{C}, \mathrm{Bq} \mathrm{kg}{ }^{-1}\right)$ of potassium, thorium, and radium were calculated using the following Equation (3) [26]:

$$
C=\frac{C P S \times 100 \times 100}{\text { B.I. } \times E_{f f} \times m} \pm \frac{S D_{C P S} \times 100 \times 100}{\text { B.I. } \times E_{f f} \times m}
$$

where $C P S$ is the net count rate per second, $S D_{C P S}$ is the standard deviation of net count rate per second, B.I. is the branching intensity, $E_{f f}$ is the efficiency of the detector, and $m$ is sample mass in $\mathrm{kg}$.

Table 2 shows the average activity concentrations of the radionuclides ${ }^{40} \mathrm{~K},{ }^{232} \mathrm{Th}$, and ${ }^{226} \mathrm{Ra}$ in structural materials used for building underground parking lots, as well as the corresponding standard deviation in the materials under investigation. It has been determined a wide range of activity concentrations of natural radionuclides contained in building materials: ${ }^{40} \mathrm{~K}-13-1217 \mathrm{~Bq} \mathrm{~kg}{ }^{-1},{ }^{226} \mathrm{Ra}-2-124 \mathrm{~Bq} \mathrm{~kg}^{-1},{ }^{232} \mathrm{Th}-1-72 \mathrm{~Bq} \mathrm{~kg}^{-1}$. The lowest activity concentrations of natural radionuclides have been found in sand, cement, and gravel, while their highest activity concentrations have been measured in ferroconcrete, clay, and concrete. The commonly used building materials samples satisfy the safety criterion of the recommended safety limit for the public [27]. Therefore, these samples do not pose any health hazard for the human.

Table 2. Activity concentrations of ${ }^{40} \mathrm{~K},{ }^{232} \mathrm{Th},{ }^{226} \mathrm{Ra}$ in studied building materials and activity indexes.

\begin{tabular}{|c|c|c|c|c|c|}
\hline & ${ }^{40} \mathrm{~K}$ & ${ }^{232} \mathrm{Th}$ & ${ }^{226} \mathrm{Ra}$ & & \\
\hline Building Material & $\begin{array}{c}\text { M.V. } \pm \sigma \\
\text { (Range) }\end{array}$ & $\begin{array}{c}\text { M.V. } \pm \sigma \\
\text { (Range) }\end{array}$ & $\begin{array}{l}\text { M.V. } \pm \sigma \\
\text { (Range) }\end{array}$ & $I_{\gamma}$ & $I_{\alpha}$ \\
\hline Clay & $\begin{array}{c}493 \pm 16 \\
(108-734)\end{array}$ & $\begin{array}{l}8 \pm 2 \\
(2-16)\end{array}$ & $\begin{array}{c}24 \pm 2 \\
(10-41)\end{array}$ & 0.28 & 0.12 \\
\hline Cement & $\begin{array}{l}126 \pm 17 \\
(13-362)\end{array}$ & $\begin{array}{l}5 \pm 1 \\
(1-8)\end{array}$ & $\begin{array}{l}39 \pm 4 \\
(7-66)\end{array}$ & 0.20 & 0.20 \\
\hline Sand & $\begin{array}{c}232 \pm 21 \\
(137-460)\end{array}$ & $\begin{array}{l}5 \pm 1 \\
(1-19)\end{array}$ & $\begin{array}{l}12 \pm 1 \\
(5-17)\end{array}$ & 0.14 & 0.06 \\
\hline Gravel & $\begin{array}{c}301 \pm 11 \\
(118-342)\end{array}$ & $\begin{array}{l}5 \pm 1 \\
(1-9)\end{array}$ & $\begin{array}{l}18 \pm 1 \\
(2-23)\end{array}$ & 0.19 & 0.09 \\
\hline Concrete & $\begin{array}{l}581 \pm 27 \\
(18-1217)\end{array}$ & $\begin{array}{l}29 \pm 3 \\
(2-47)\end{array}$ & $\begin{array}{l}44 \pm 3 \\
(3-92)\end{array}$ & 0.48 & 0.22 \\
\hline Ferroconcrete & $\begin{array}{c}603 \pm 21 \\
(47-1108)\end{array}$ & $\begin{array}{c}34 \pm 4 \\
(1-72)\end{array}$ & $\begin{array}{c}90 \pm 4 \\
(4-124)\end{array}$ & 0.67 & 0.45 \\
\hline
\end{tabular}

The values of activity indexes $I_{\gamma}$ and $I_{\alpha}$ are given in Table 2 . These indexes are used for the overall evaluation of building materials from the view of radiation protection.

The gamma activity index $\left(I_{\gamma}\right)$ is calculated using the following Equation (4):

$$
I_{\gamma}=\frac{C_{\mathrm{Ra}}}{300}+\frac{C_{\mathrm{Th}}}{200}+\frac{C_{\mathrm{K}}}{3000}
$$

where $C_{\mathrm{Ra}}, C_{\mathrm{Th}}, C_{\mathrm{K}}$ are activity concentrations of ${ }^{226} \mathrm{Ra},{ }^{232} \mathrm{Th}$, and ${ }^{40} \mathrm{~K}$ in $\mathrm{Bq} \mathrm{kg}{ }^{-1}$.

The gamma activity indexes of natural radionuclides in building materials varied from 0.14 to 0.67 . They did not exceed the values determined by the Lithuanian Hygiene Norm [28] and regulated by the European Commission [29].

Alpha index $\left(I_{\alpha}\right)$ assesses internal hazards originating from the alpha activity of building materials. This parameter evaluates the exposure level due to radon inhalation originating from building materials. The $I_{\alpha}$ has been proposed by S. Righi [30]. 
The alpha index calculated using Equation (5).

$$
I_{\alpha}=\frac{C_{\mathrm{Ra}}}{200}
$$

The activities of radium must not exceed a value of $200 \mathrm{~Bq} \mathrm{~kg}^{-1}$, to avoid exposure to the indoor radon concentration of more than $200 \mathrm{~Bq} \mathrm{~m}^{-3}$. In this work, the alpha index ranged from 0.06 to 0.45 from building materials. The highest value of $I_{\alpha} 0.45$ was found in ferroconcrete samples as well as the highest value of $I_{\gamma} 0.67$.

The values of activity concentration index $I_{\alpha}$ and $I_{\gamma}$ regulated by the European Commission radiation protection principles shall not exceed 0.5 and 1, respectively [29].

It is known that the absorbed dose rate is not directly related to radionuclide concentrations in constructions materials. Other parameters that are important for dose rate indoors are analyzed below.

\subsection{Evaluation of Radiological Hazard Parameters in Building Materials}

\subsubsection{Radium Equivalent Activity}

The natural radioactivity of construction materials is usually determined from the content of natural radionuclides ${ }^{40} \mathrm{~K},{ }^{232} \mathrm{Th}$, and ${ }^{226} \mathrm{Ra}$. The distribution of these radionuclides in building materials samples under investigation is not uniform; therefore, a radium equivalent activity index $\left(R a_{\mathrm{eq}}\right)$ was introduced. $R a_{\mathrm{eq}}$ is an index used to represent the activity concentrations of ${ }^{40} \mathrm{~K},{ }^{232} \mathrm{Th}$, and ${ }^{226} \mathrm{Ra}$ by a single quantity, which takes into account the radiation hazards associated with them. $R a_{\mathrm{eq}}$ is calculated according to the following Equation (6):

$$
R a_{\mathrm{eq}}=C_{\mathrm{Ra}}+1.43 C_{\mathrm{Th}}+0.077 C_{\mathrm{K}}
$$

The calculated values of $R a_{\mathrm{eq}}$ for all types of building materials ranged from 37.01 to $185.05 \mathrm{~Bq} \mathrm{~kg}^{-1}$, which is less than the limit of $370 \mathrm{~Bq} \mathrm{~kg}^{-1}[17,31-33]$. This value is defined by the Organization for Economic Cooperation and Development to keep the external dose below $1.5 \mathrm{mSv} \mathrm{y}^{-1}$. The highest value of $R a_{\mathrm{eq}}$ is estimated in ferroconcrete samples (Table 3).

\begin{tabular}{|c|c|c|c|c|c|c|}
\hline Building Material & $\begin{array}{c}R a_{\mathrm{eq}} \\
\left(\mathrm{Bq} \mathrm{kg}^{-1}\right)\end{array}$ & $\begin{array}{c}\text { Average Absorbed } \\
\text { Dose Rate }\left(\mathrm{nGy} \mathrm{h}^{-1}\right)\end{array}$ & $\begin{array}{l}\text { Outdoor Annual } \\
\text { Effective Dose } \\
\text { (mSv) }\end{array}$ & $\begin{array}{l}\text { Indoor Annual } \\
\text { Effective Dose } \\
\text { (mSv) }\end{array}$ & $H_{\mathrm{ex}}$ & $H_{\text {in }}$ \\
\hline Clay & 73 & 36 & 0.045 & 0.18 & 0.20 & 0.26 \\
\hline Cement & 56 & 26 & 0.032 & 0.13 & 0.15 & 0.26 \\
\hline Sand & 37 & 18 & 0.022 & 0.09 & 0.10 & 0.13 \\
\hline Gravel & 48 & 24 & 0.029 & 0.12 & 0.13 & 0.18 \\
\hline Concrete & 130 & 62 & 0.076 & 0.31 & 0.35 & 0.47 \\
\hline Ferroconcrete & 185 & 87 & 0.107 & 0.43 & 0.50 & 0.74 \\
\hline
\end{tabular}

Table 3. The average values of absorbed dose rate, annual effective dose, and hazard parameters for building materials.

The results show that $R a_{\mathrm{eq}}$ of different building materials can vary significantly. This is important in choosing the appropriate materials for building constructions. Actually, $R a_{\mathrm{eq}}$ of the same type of building materials can have large variations. Therefore, it is important to identify their radioactivity levels before using building materials.

\subsubsection{Absorbed and Annual Effective Dose Rate}

Gamma radiation hazards related to building materials can be evaluated by calculating the different radiation hazard parameters [34]. One of the parameters to estimate radiation risk to humans is absorbed dose rate $(D)$. The absorbed dose rate can be calculated by the concentrations of ${ }^{40} \mathrm{~K},{ }^{226} \mathrm{Ra}$, and ${ }^{232} \mathrm{Th}$ by applying the conversion factors $0.0417,0.462$, 
and 0.604 for potassium, radium, and thorium, respectively [32]. These conversion factors were used to calculate the total absorbed gamma dose rate in the air of underground car parks at $1 \mathrm{~m}$ above the ground level. The absorbed dose rate has been calculated by using the Monte Carlo method [35]:

$$
D=0.0417 C_{\mathrm{K}}+0.462 C_{\mathrm{Ra}}+0.604 C_{\mathrm{Th}}
$$

where $D$ is the absorbed dose rate $\left(n G y \mathrm{~h}^{-1}\right)$.

To determine annual effective dose $(A E D)$ the conversion coefficient from absorbed dose to effective dose and the indoor and outdoor occupancy factor must be taken into account. The conversion coefficient from absorbed dose rate in the air to effective dose is $0.7 \mathrm{~Sv} \mathrm{~Gy}{ }^{-1}$, which is used to convert the absorbed dose rate to human effective dose equivalent with an outdoor occupancy of $20 \%$ and $80 \%$ for indoors, proposed by [32].

The annual effective doses are calculated as follows:

$$
\begin{aligned}
& A E D_{\text {outdoor }}=0.2 \times D \times t \times F \times 10^{-6} \\
& A E D_{\text {indoor }}=0.8 \times D \times t \times F \times 10^{-6}
\end{aligned}
$$

where $A E D$ is the annual effective dose $\left(\mathrm{mSv} \mathrm{y}^{-1}\right) ; D$ is absorbed dose rate $\left(\mathrm{nGy} \mathrm{h}^{-1}\right) ; t$ is the duration of the exposure $(8760 \mathrm{~h}) ; F$ is the conversion factor of $0.7 \mathrm{~Sv} \mathrm{~Gy}^{-1}$.

Applying Equations (7)-(9), the absorbed and annual effective dose rates from the samples were calculated, as given in Table 3 . The average values of the calculated absorbed dose rate in samples ranged from $18.24 \mathrm{nGy} \mathrm{h}^{-1}$ in the sand to $87.26 \mathrm{nGy} \mathrm{h}^{-1}$ in ferroconcrete. The values of $A E D_{\text {indoor }}$ were found to vary from 0.09 to $0.43 \mathrm{mSv} \mathrm{y}^{-1}$. $A E D_{\text {outdoor }}$ varied from 0.022 to $0.107 \mathrm{mSv} \mathrm{y}^{-1}$. The annual effective dose from ferroconcrete is higher than the other samples. The lowest annual effective dose was found in sand and gravel. However, it was estimated that all these building materials samples satisfy the safety criteria for radiation safety point of view, and hence, these samples do not pose any environmental and health hazard problems. The calculated annual effective dose is below the limit of $1.0 \mathrm{mSv} \mathrm{y}^{-1}$ recommended by the International Commission on Radiological Protection for the general public.

\subsubsection{External and Internal Hazard Index}

The values of external $\left(H_{\mathrm{ex}}\right)$ and internal $\left(H_{\mathrm{in}}\right)$ hazards are shown in Table 3.

External hazard index is calculated using Equation (10) [36,37].

$$
H_{\mathrm{ex}}=\frac{C_{\mathrm{Ra}}}{370}+\frac{C_{\mathrm{Th}}}{259}+\frac{C_{\mathrm{K}}}{4810} \leq 1 .
$$

Internal hazard index is calculated using the following Equation (11) [36,37]:

$$
H_{\text {in }}=\frac{C_{\mathrm{Ra}}}{185}+\frac{C_{\mathrm{Th}}}{259}+\frac{C_{\mathrm{K}}}{4810} \leq 1
$$

The values of these indices must be lower than 1 , to ensure that the radiation hazard is insignificant in the investigated area [32,38].

As can be seen, the maximum values of $H_{\mathrm{ex}}$ and $H_{\mathrm{in}}$ are found in ferroconcrete samples, 0.50 and 0.74 , respectively. The values of $H_{\mathrm{ex}}$ and $H_{\mathrm{in}}$ are all below unity; therefore, the materials analyzed in this study can be safely used for the construction of buildings.

\subsection{Estimation of Equivalent Dose Rate Caused by Radon}

Consistently registering the records of the dosimeter, information on the equivalent dose rate of parking places was collected. The equivalent dose rate is influenced by ionizing radiation of radionuclides in the ground surface and air as well as cosmic radiation [39].

External equivalent dose rate $(E D R)$ values caused by radiation of natural radionuclides, respectively, ${ }^{40} \mathrm{~K},{ }^{226} \mathrm{Ra}$, and ${ }^{232} \mathrm{Th}$ are presented in Figure 2 . To evaluate the 
measured equivalent dose rate in the underground parking lots, the results were compared with the measurement results in the aboveground parking lots. Figure 2 shows the equivalent dose rate measured in artificial ventilated underground parking lots and natural ventilated aboveground parking lots.

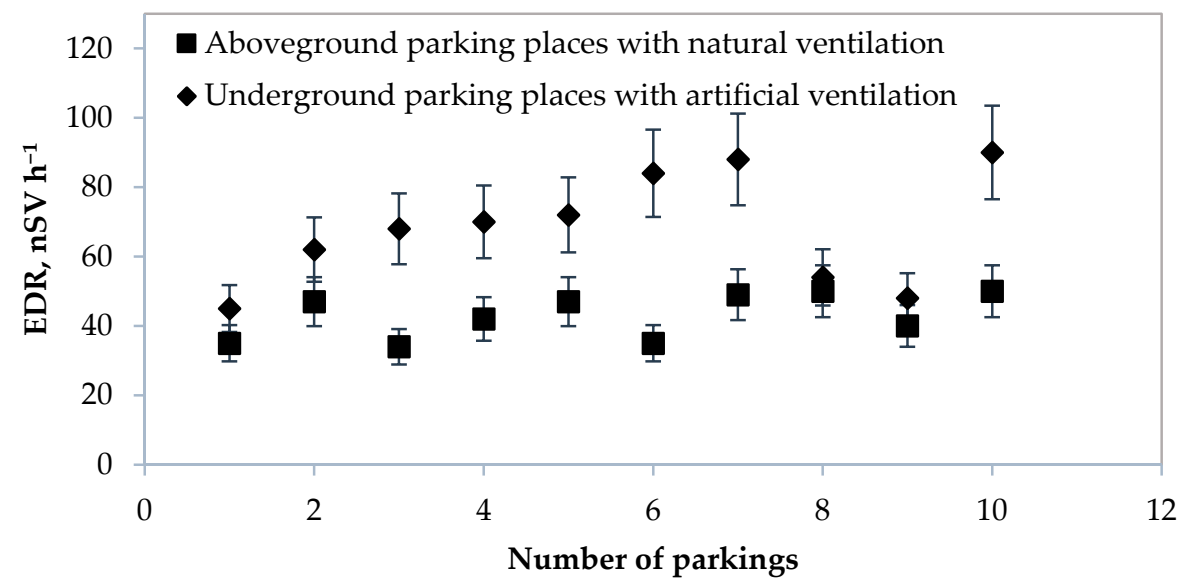

Figure 2. Equivalent dose rate (EDR) in different types of parking lots.

Experiments show that the highest values of $E D R$ are measured in underground parking lots with artificial ventilation. About $2-20 \%$ of the radiation is radon progeny in these parking places, and this is explained by the fact that the biggest amount of radon is in the soil, and it tends to accumulate specifically in rooms and underground structures that are in contact with the ground [40].

Figure 3 shows a variation of the equivalent dose rate caused by radon and the total equivalent dose rate. $E D R$ was measured and the ${ }^{222} \mathrm{Rn}$ activity concentration in the air was determined in the underground parking lots at the same time to estimate which part of the total EDR is due to the ${ }^{222} \mathrm{Rn}$.

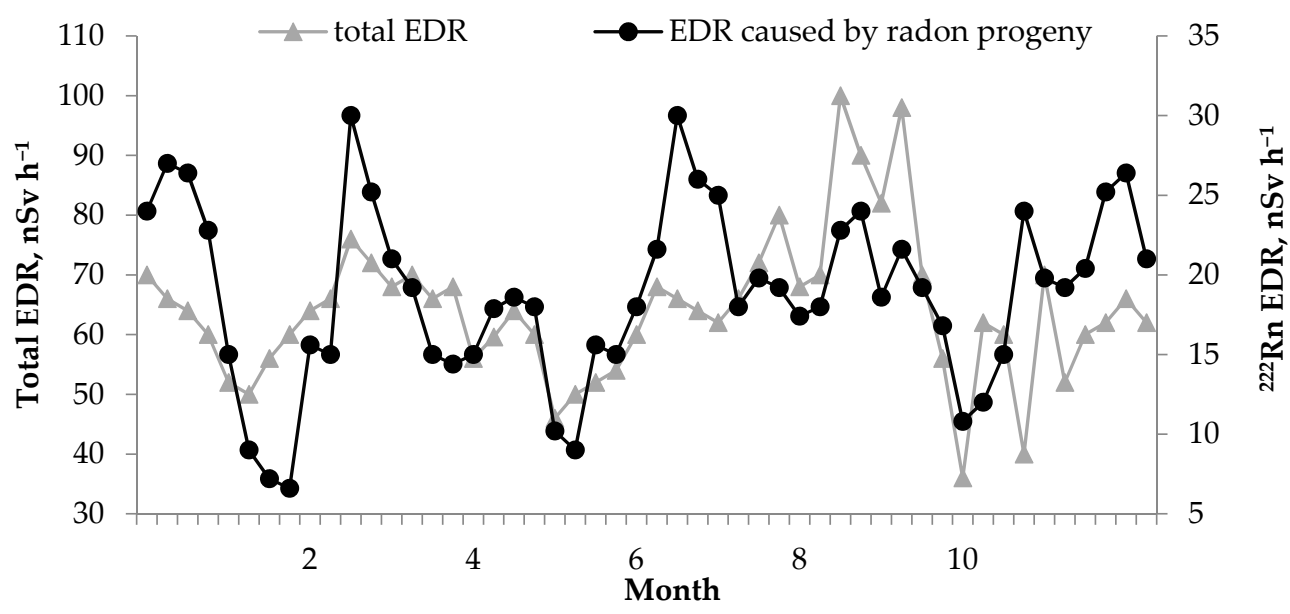

Figure 3. Variations of the equivalent dose rate caused by ${ }^{222} \mathrm{Rn}$ and total equivalent dose rate in the underground parking lots.

It was evaluated that $E D R$ caused by the ${ }^{222} \mathrm{Rn}$ and its progeny varies from 17 to $30 \%$ of the total EDR in the underground parking lots. Radon activity concentration can be reduced by using radon exhalation from the ground and building materials blocking means: seal cracks, cover surfaces (e.g., paint), fill pores, and others. It is important to ventilate underground parking lots more frequently. Additionally, building materials with the lowest ${ }^{226} \mathrm{Ra}$ activity concentration should reduce radon and its progeny concentration. 


\section{Conclusions}

Activity concentrations of ${ }^{40} \mathrm{~K},{ }^{232} \mathrm{Th}$, and ${ }^{226} \mathrm{Ra}$ in the building materials used for construction underground parking lots were determined. The highest values were found in concrete and ferroconcrete samples: ${ }^{40} \mathrm{~K} 581$ and $603 \mathrm{~Bq} \mathrm{~kg}^{-1}, 232 \mathrm{Th} 29$ and $34 \mathrm{~Bq} \mathrm{~kg}^{-1}$, ${ }^{226} \mathrm{Ra} 44$ and $90 \mathrm{~Bq} \mathrm{~kg}{ }^{-1}$, respectively. A statistically significant positive correlation (i.e., 0.88 ) between radium activity concentration in building materials and radon concentration in underground parking lots has been found. The highest values of radon exhalation were determined in ferroconcrete samples. The radon exhalation rates showed a good correlation with radium concentration.

It was estimated that the values of external $\left(H_{\mathrm{ex}}\right)$ and internal $\left(H_{\text {in }}\right)$ hazard indexes in the studied samples were lower than the recommended limits. The calculated values of $H_{\mathrm{ex}}$ and $H_{\mathrm{in}}$, as well as the values of gamma $\left(I_{\gamma}\right)$ and alpha $\left(I_{\alpha}\right)$ activity indexes, were below the recommended level of 1 . Therefore, it is safe to use the materials analyzed in this study for the construction of underground parking lots.

Having assessed the possible additional exposure induced by the radioactivity of the building materials contained in underground parking lots, it was established that the absorbed dose rate $(D)$ and annual effective dose $(A E D)$ increase up to 2.5 times; however, they do not exceed the maximum permissible rates of natural exposure. The studied areas may be considered safe from a radiological point of view. The calculated radium equivalent activity $\left(R a_{\mathrm{eq}}\right)$ was below the upper limit of $370 \mathrm{~Bq} \mathrm{~kg}^{-1}$ in all types of building materials.

The equivalent dose rate $(E D R)$ in artificial ventilated underground and natural ventilated aboveground parking lots was experimentally determined. It was estimated that the highest values of $E D R$ are measured in artificial ventilated underground parking lots and EDR caused by the radon, and its progeny varies from 17 to $30 \%$ of the total EDR.

Author Contributions: Conceptualization, D.J. and M.P.; methodology, D.J. and M.P.; validation, D.J. and M.P.; formal analysis, M.P.; investigation, D.J. and M.P.; resources, D.J. and M.P.; data curation, D.J. and M.P.; writing—original draft preparation, D.J. and M.P.; writing—review and editing, D.J. and M.P.; visualization, D.J.; supervision, D.J. All authors have read and agreed to the published version of the manuscript.

Funding: This research received no external funding.

Institutional Review Board Statement: Not applicable.

Informed Consent Statement: Not applicable.

Data Availability Statement: Not applicable.

Conflicts of Interest: The authors declare no conflict of interest.

\section{References}

1. Faghihi, R.; Mehdizadeh, S.; Sina, S. Natural and artificial radioactivity distribution in soil of Fars province, Iran. Radiat. Prot. Dosim. 2011, 145, 66-74. [CrossRef] [PubMed]

2. Mehra, R.; Kumar, S.; Sonkawade, R.; Singh, N.P.; Badhan, K. Analysis of terrestrial naturally occurring radionuclides in soil samples from some areas of Sirsa district of Haryana, India using gamma ray spectrometry. Environ. Earth Sci. 2010, 59, 1159-1164. [CrossRef]

3. Stoulos, S.; Manolopoulo, M.; Papastefanou, C. Assessment of natural radiation exposure and radon exhalation from building materials in Greece. J. Environ. Radioact. 2003, 69, 225-240. [CrossRef]

4. United Nations Scientific Committee on the Effects of Atomic Radiation. Sources and Effects of Ionizing Radiation. Report to the General Assembly, with Scientific Annexes 2008; United Nations: New York, NY, USA, 2010.

5. United Nations Scientific Committee on the Effects of Atomic Radiation. Report of the United Nations Scientific Committee on the Effects of Atomic Radiation 2010; United Nations: New York, NY, USA, 2011.

6. Trevisi, R.; Nuccetelli, C.; Risica, S. Screening tools to limit the use of building materials with enhanced/elevated levels of natural radioactivity: Analysis and application of index criteria. Constr. Build. Mater. 2013, 49, 448-454. [CrossRef]

7. Leung, J.K.C.; Tso, M.Y.W.; Ho, C.W.; Hung, L.C. Radon mitigation in a typical underground car park in Hong Kong. Radiat. Protect. Dosim. 1997, 71, 289-296. [CrossRef]

8. Lebedyte, M.; Butkus, D.; Morkunas, G. Variations of the ambient dose equivalent rate in the ground level air. J. Environ. Radioact. 2003, 64, 45-57. [CrossRef] 
9. Chibowski, S.; Komosa, A. Radon concentration in basements of old town buildings in the Lublin region, Poland. J. Radioanal. Nucl. Chem. 2001, 247, 53-56. [CrossRef]

10. Al-Jundi, J.; Salah, W.; Bawa'aneh, M.S.; Afaneh, F. Exposure to radiation from the natural radioactivity in Jordanian building materials. Radiat. Prot. Dosim. 2006, 118, 93-96. [CrossRef]

11. Lithuanian Hygiene Norm HN 73: 2018. Basic Radiation Protection Standards. Available online: https://e-seimas.lrs.lt/portal/ legalAct/lt/TAD/TAIS.159355/asr (accessed on 5 August 2021). (In Lithuanian).

12. Official Journal of the European Union. Council Directive 2013/59/Euratom; Official Journal of the European Union: Luxembourg, 2015.

13. Moharram, B.M.; Suliman, M.N.; Zahran, N.F.; Shennawy, S.E.; El-Sayed, A.R. External exposure doses due to gamma emitting natural radionuclides in some Egyptian building materials. Appl. Radiat. Isot. 2012, 70, 241-248. [CrossRef] [PubMed]

14. Trevisi, R.; Risica, S.; D'Alessandro, M.; Paradiso, D.; Nuccetelli, C. Natural radioactivity in building materials in the European Union: A database and an estimate of radiological significance. J. Environ. Radioact. 2012, 105, 11-20. [CrossRef]

15. Sonkawadea, R.G.; Kantb, K.; Muralithara, S.; Kumara, R.; Ramola, R.C. Natural radioactivity in common building construction and radiation shielding materials. Atmos. Environ. 2008, 42, 2254-2259. [CrossRef]

16. Moura, C.L.; Artur, A.C.; Bonotto, D.M.; Guedes, S.; Martinelli, C.D. Natural radioactivity and radon exhalation rate in Brazilian igneous rocks. Appl. Rad. Isot. 2011, 69, 1094-1099. [CrossRef]

17. Jasaitis, D.; Chadysiene, R.; Peciuliene, M.; Vasiliauskiene, V. Research on change of natural ionizing radiation in car parking places. Rom. J. Phys. 2016, 61, 1567-1576.

18. Perna, A.F.N.; Paschuk, S.A.; Corrêa, J.N.; Narloch, D.C.; Barreto, R.C.; Del Claro, F.; Denyak, V. Exhalation rate of radon-222 from concrete and cement mortar. Nukleonika 2018, 63, 65-72. [CrossRef]

19. Roelofs, L.M.M.; Scholten, L.C. The effect of aging, humidity and fly-ash additive on the radon exhalation from concrete. Health Phys. 1994, 67, 206-271. [CrossRef]

20. Yu, K.N.; Young, E.C.M.; Chan, T.F.; Lo, T.; Balendran, R.V. The variation of radon exhalation rates from concrete surfaces of different ages. Build. Environ. 1996, 31, 255-257. [CrossRef]

21. Taylor-Lange, S.C.; Stewart, J.G.; Juenger, M.C.G.; Siegel, J.A. The contribution of fly ash toward indoor radon pollution from concrete. Build. Environ. 2012, 56, 276-282. [CrossRef]

22. Leonardi, F.; Bonczyk, M.; Nuccetelli, C.; Wysocka, M.; Michalik, B.; Ampollini, M.; Tonnarini, S.; Rubin, J.; Niedbalska, K.; Trevisi, R. A study on natural radioactivity and radon exhalation rate in building materials containing norm residues: Preliminary results. Constr. Build. Mater. 2018, 173, 172-179. [CrossRef]

23. Stajic, M.; Nikezic, D. Measurement of radon exhalation rates from some building materials used in Serbian construction. J. Radioanal. Nucl. Chem. 2015, 303, 1943-1947. [CrossRef]

24. Dabayneh, K.M. ${ }^{222}$ Rn concentration level measurements and exhalation rates in different types of building materials used in Palestinian buildings. Isot. Radiat. Res. J. 2008, 40, 277-289.

25. Bala, P.; Kumar, V.; Mehra, R. Measurement of radon exhalation rate in various building materials and soil samples. J. Earth Syst. Sci. 2017, 126, 1-8. [CrossRef]

26. Hussain, R.O.; Hussain, H.H. Investigation the Natural Radioactivity in Local and Imported Chemical Fertilizers. Braz. Arch. Biol. Technol. 2011, 54, 777-782. [CrossRef]

27. ICRP. International Commission on Radiological Protection. Available online: http://icrpaedia.org/Dose_limits (accessed on 30 April 2021).

28. Lithuanian Hygiene Norm HN 85: 2011. Natural Exposure. Radiation Protection Standards. Available online: https:/ /e-seimas. lrs.lt/portal/legalAct/lt/TAD/TAIS.408807 (accessed on 30 April 2021). (In Lithuanian).

29. European Commission. Radiological Protection Principles Concerning the Natural Radioactivity of Building Materials. Radiation Protection 112; Directorate General Environment, Nuclear Safety and Civil Protection: Luxembourg, 1999; Available online: https:/ / op.europa.eu/en/publication-detail/- / publication/988f3243-5259-43a5-b621-fbff662deeb0/language-en (accessed on 30 April 2021).

30. Righi, S.; Bruzzi, L. Natural radioactivity and radon exhalation in building materials used in Italian dwellings. J. Environ. Radioact. 2006, 88, 158-170. [CrossRef]

31. Mujahid, S.A.; Rahim, A.; Hussain, S.; Farooq, M. Measurements of natural radioactivity and radon exhalation rates from different brands of cement used in Pakistan. Radiat. Prot. Dosim. 2008, 130, 206-212. [CrossRef]

32. United Nations Scientific Committee on the Effects of Atomic Radiation. Sources and Effects of Lonizing Radiation. Report of the United Nations Scientific Committee on the Effects of Atomic Radiation to the General Assembly; United Nations: New York, NY, USA, 2000.

33. Organization for Economic Cooperation and Development (OECD). Exposure to Radiation from Natural Radioactivity in Building Materials; Report by a Group of Experts of the OECD Nuclear Energy Agency; OECD: Paris, France, 1979.

34. Varshney, R.; Mahur, A.K.; Sonkawade, R.G.; Suhail, M.A.; Azam, A.; Prasad, R. Evaluation and analysis of ${ }^{226} \mathrm{Ra},{ }^{232} \mathrm{Th},{ }^{40} \mathrm{~K}$ and radon exhalation rate in various grey cements. Indian J. Pure Appl. Phys. 2010, 48, 473-477.

35. Ibraheem, A.A.; El-Taher, A.; Alruwaili, M.H. Assessment of natural radioactivity levels and radiation hazard indices for soil samples from Abha, Saudi Arabia. Res. Phys. 2018, 11, 325-330. [CrossRef]

36. Mehdizadeh, S.; Faghihi, R.; Sina, S. Natural radioactivity in building materials in Iran. Nukleonika 2011, 56, 363-368. 
37. El-Taher, A. Gamma spectroscopic analysis and associated radiation hazards of building materials used in Egypt. Radiat. Prot. Dosim. 2010, 138, 166-173. [CrossRef] [PubMed]

38. Beretka, J.; Matthew, P.J. Natural radioactivity of Australian building materials, waste and by-products. Health Phys. 1985, 48, 87-95. [CrossRef]

39. Ademola, A.K.; Belloa, A.K.; Adejumobi, A.C. Determination of natural radioactivity and hazard in soil samples in and around gold mining area in Itagunmodi, south-western, Nigeria. J. Rad. Res. Appl. Sci. 2014, 7, 249-255. [CrossRef]

40. Ptiček Siroci, A.; Stanko, D.; Sakač, N.; Dogančic, D.; Trojko, T. Short-Term Measurement of Indoor Radon Concentration in Northern Croatia. Appl. Sci. 2020, 10, 2341. [CrossRef] 